\title{
First description of a herpesvirus infection in genus Lepus
}

\author{
Abade dos Santos, F.A. ${ }^{1,2^{*}}$, Monteiro, M. ${ }^{1}$, Pinto, A. ${ }^{3}$, Carvalho, C.L. ${ }^{1}$, Peleteiro \\ M.C. ${ }^{2}$, Carvalho, P. ${ }^{1}$, Mendonça, P. ${ }^{1}$, Carvalho, T. ${ }^{3}$, Duarte, M.D. ${ }^{1,2}$
}

\section{Author Details}

Abade dos Santos, F.A. ${ }^{1,2}$ DVM, MSc

Monteiro, M. ${ }^{1}$ DVM

Pinto, A. ${ }^{3,4}$ BMSc, MSc

Carvalho, C.L. ${ }^{2}$, DVM, PhD

Peleteiro, M.C. ${ }^{1}$, DVM, PhD

Carvalho, P. ${ }^{1}$ DVM

Mendonça, P. ${ }^{1}$ DVM

Carvalho, T. ${ }^{3}$, DVM, PhD

Duarte, M.D. ${ }^{2}$, DVM, MSc, PhD

${ }^{1}$ Instituto Nacional de Investigação Agrária e Veterinária, Av. da República, Quinta do Marquês, 2780-157 Oeiras, Portugal

${ }^{2}$ CIISA, Faculdade de Medicina Veterinária, Universidade de Lisboa, Avenida da Universidade Técnica, 1300-477 Lisboa, Portugal

${ }^{3}$ Instituto de Medicina Molecular João Lobo Antunes, Faculdade de Medicina, Universidade de Lisboa, Avenida Professor Egas Moniz, 1649-028 Lisboa, Portugal

${ }^{4}$ EM Suite, Royal Brompton Hospital and Harefield NHS Foundation Trust

\section{Corresponding author:}

Abade dos Santos, F.A.

Faculdade de Medicina Veterinária, Avenida da Universidade Técnica 1300-477 Lisboa, Portugal

Instituto Nacional de Investigação Agrária e Veterinária, Av. da República, Quinta do Marquês, 2780-157 Oeiras, Portugal

faas@fmv.ulisboa.pt +351213652800

\section{Key words}

Herpesviruses, Gammaherpesvirinae, European hare, Lepus granatensis, Leporids Running title: First Herpesvirus in Iberian hare. 


\section{Funding}

Most of the field and laboratory work referred to in this manuscript was supported by the Fundação para a Ciência e Tecnologia (FCT) (Grant SFRH/BD/137067/2018), by Fundo Florestal Permanente (Government of Portugal) in the scope of the Action Plan for the Control of Rabbit Viral Haemorrhagic Disease (+COELHO, Dispatch no.

$4757 / 2017$ of 31 May), and by the Interdisciplinary Research Centre on Animal Health, Faculty of Veterinary Medicine, University of Lisbon (CIISA, FMV-UL) (Portugal) (Project UID/CVT/00276/2013).

Funding bodies played no direct role in the design or conclusion of the study.

\section{Authors' contributions}

Abade dos Santos, F.A.: Experimental design. Collection of animals, Necropsies, Sequencing, Histopathology analysis. Wrote the manuscript.

Monteiro, M.: Performed necropsies, Sequencing, Histopathology analysis and lesion pattern study.

Pinto, A.: Preformed all the EM analysis.

Carvalho C.L.: Wrote the manuscript.

Peleteiro, M.C.: Histopathology analysis. Revised the manuscript.

Carvalho, P.: Performed the necropsies.

Mendonça, P.: Performed the necropsies.

Carvalho, T.: Interpretation of EM resuts.

Duarte, M.D.: Data collection and data analysis. Wrote and revised the manuscript.

\section{Acknowledgements}

We thank Sebastião Miguel (Hunting manager), João Carvalho (ANPC), Jacinto Amaro (FENCAÇA), Fernando Castanheira Pinto (CNCP) and Duarte Nuno (ICNF), for sample collection and organization of the sampling events. We are also grateful to Dr. Teresa Fagulha (INIAV, Virology Laboratory) for help with molecular characterization and to Maria João Teixeira (INIAV, Virology Laboratory) for technical assistance. Finally, we also thank to all the hunters who participated in fieldwork and sample collection.

\section{Declarations}

This study did not use live animals and was carried out within the scope of a National Plan for the Control of Rabbit Haemorrhagic Disease Virus 2 in rabbits (Dispatch no. 4757/2017 of 31 May), with the legal authorizations from the National Authority-the Institute for Nature Conservation and Forests (Instituto da Conservação da Natureza e das Florestas, I.P., ICNF). 


\section{Abstract}

During the necropsies of Iberian hares obtained in 2018/2019, along with signs of the nodular form of myxomatosis, other unexpected external lesions were also observed. Histopathology revealed nuclear inclusion bodies in stromal cells suggesting the additional presence of a nuclear replicating virus.

Transmission electron microscopy further demonstrated the presence of herpesvirus particles in the tissues of affected hares.

We confirmed the presence of herpesvirus in 13 MYXV-positive hares by PCR and sequencing analysis. Herpesvirus-DNA was also detected in seven healthy hares, suggesting its asymptomatic circulation.

Phylogenetic analysis based on DNA polymerase gene, grouped this virus within the gammaherpesviruses, close to herpesviruses from bats and rodents.

We propose to name this new virus Leporid gammaherpesvirus 5 (LeHV-5), according to the International Committee on Taxonomy of Viruses standards.

The impact of herpesvirus infection on the reproduction and mortality of the lberian hare is yet unknown but may aggravate the decline of wild populations caused by the recently emerged natural recombinant myxoma virus. 


\section{Introduction}

The Iberian hare (Lepus granatensis), also known as Granada hare, is an endemic specie of the Iberian Peninsula whose populations are considered stable by the IUCN holding a 'minor concern' conservation status[1].

Lepus granatensis is the only hare species found in Portugal and the most widespread in the Iberia[2], therefore, highly relevant for biodiversity preservation and hunting activity in both countries, particularly for greyhound racing.

Contrarily to the wild rabbit, which drastic decline has been linked, among other factors, to viral epizooties, until recently, the Iberian hare was not affected by viral diseases. Environmental and anthropogenic factors, however, have had a negative impact on both hare and wild-rabbit populations.

Lepus granatensis was considered naturally resistant to myxomatosis, which is endemic in Iberian Peninsula since 1956[3], despite very sporadic reports of the disease in the European brown hare (L. europaeus), namely in France and Ireland[4-6]. However, during the summer and autumn of 2018 outbreaks of myxomatosis in the Iberian hare were reported in Spain[7] and Portugal [8], respectively.

No other diseases of viral origin have been described in the lberian hare, including those caused by herpesviruses, which may have a fatal outcome in rabbits [9].

Until now, four herpesviruses have been identified in leporids: Leporid herpesvirus 1 (LeHV-1), Leporid herpesvirus 2 (LeHV-2), Leporid herpesvirus 3 (LeHV-3) and Leporid herpesvirus 4 (LeHV-4) (Table 1). Of these, the most common naturally occurring herpesvirus infections identified in rabbits are LeHV-2 and LeHV-3 (reviewed by [9]), which alongside LeHV-1 belong to the Gammaherpesvirinae subfamily. Conversely, LeHV-4 is a member of the Alphaherpesvirinae subfamily. These distinct herpesviruses have a broadly variable impact on the European rabbit, with LeHV-2 and LeHV-3 infections usually passing unnoticed [10], while LeHV-4 is far more aggressive, causing fatal infections [9].

Herpesviruses are enveloped viruses, of 200-250 nm in diameter, organised in four concentric layers[11], 1) a core with the linear dsDNA genome , 2) $T=16$ icosahedral capsid with about $125 \mathrm{~nm}$ of diameter surrounded by a 3 ) proteinaceous tegument that contains many virus-coded proteins and enclosed in a 4) lipid envelope containing several viral glycoproteins. Morphologically, herpesviruses are distinct from all other viruses[12], and therefore easily recognised by electron microscopy.

Herpesviruses belong to order Herpesvirales that comprises three families, namely the Herpesviridae family, which includes more than 100 viruses of mammals, birds and reptiles and whose members have large genomes ranging from 125 to $290 \mathrm{~kb}[13]$, the 
Alloherpesviridae family, which includes the fish and frog viruses, and the Malacoherpesviridae family, which contains the bivalve virus[12].

The Herpesviridae family includes the subfamilies Alphaherpesvirinae, Betaherpesvirinae and Gammaherpesvirinae. Their members have different biologic properties and distinct classification, supported by phylogeny. The Gammaherpesvirinae subfamily is divided into four genera, namely Macavirus, Percavirus, Lymphocryptovirus, and Rhadinovirus[12].

While the subfamily Alphaherpesvirinae causes rapid lysis in cell culture, members of Betaherpesvirinae grow slowly inducing the formation of giant cells in culture, and Gammaherpesvirinae typically infect lymphoid tissue, meaning a primary tropism for lymphoid lineage cells[14], which can lead to lymphoproliferative diseases[9] and oncogenesis[13].

In this study, we investigated the presence of herpesvirus in myxoma virus (MYXV)positive hares that alongside, the typical myxoma virus-induced skin lesions, presented other lesions in the genitalia, eyelids, lips and nose suggestive of herpesvirus infection. To unveil the prevalence of herpesvirus in the hare populations, healthy hares were also investigated.

\section{Materials and Methods}

\subsection{Sample}

A total of 38 Iberian hares, none sacrificed for the purpose of this study, were investigated within the scope of a national surveillance program (Dispatch 4757/17, 31th may)[8] in action since August 2017. Of these, 16 were males, 20 were females, and two failed sexdetermination. Eighteen hares were legally hunted by the Hunting Associations during the $2018 / 2019$ season (October to December), authorized by permits from the National Forest Authority, the Institute for Nature Conservation and Forests (ICNF), while 20 were found dead in the field between October 2018 and June 2019. None of the authors were responsible for the death of the animals. Hunted and hares found dead were sampled in six Districts of mainland Portugal, namely Setúbal, Santarém, Beja, Évora, Portalegre and Faro, (Figure 1).

\subsection{Necropsy and Histopathology}

Cadavers were necropsied and spleen, liver, lung, duodenum and skin samples (namely scrotum, lips and nose) were collected for virology, bacteriology and histopathology. The entire gastrointestinal tract was taken for parasitological analysis. From hunted hares, only spleen, liver and lung samples were received at the laboratory. 
For histopathology, skin and genitalia fragments were fixated in 10\% neutral buffered formalin, routinely paraffin embedded, sectioned at $4 \mu \mathrm{m}$, and stained with Hematoxylin and Eosin (H\&E).

\subsection{Transmission electron microscopy}

The fragments selected for transmission electron microscopy (TEM) were formalin fixated for $48 \mathrm{~h}$ or on a solution $0.1 \mathrm{M}$ sodium cacodylate (Sigma(C) containing $2.5 \%$ gluteraldehyde (Sigma@) for $72 \mathrm{~h}$. When the samples were already embebed in paraffin, the regions of interest were extracted from the block, sliced smaller than $\sim 1 \mathrm{~mm}^{3}$ with a scalpel blade into two separate viles, and washed thoroughly in xylene. After rehydration using decreasing concentrations of ethanol, fragments were washed in $0.1 \mathrm{M}$ cacodylate buffer[15]. Samples were then post-fixed with $2 \%$ osmium tetroxide (EMS) for $30 \mathrm{~min}$, and stained in block with 1\% Millipore-filtered uranyl acetate (Agar Scientifics), after which they were dehydrated in increasing concentrations of ethanol, infiltrated and embedded in EMBed-812 hard (EMS). Polymerization was performed at $60^{\circ} \mathrm{C}$ for 2 days. Ultrathin sections were cut either in a UC7 ultramicrotome or in a Reichert ultracut E ultramicrotome (Leica), collected to $1 \%$ formvar coated copper slot grids (Agar scientific), stained with uranyl acetate and lead citrate (Sigma) and examined in a H-7000 transmission electron microscope (Hitachi) at an accelerating voltage of $100 \mathrm{kV}$ or Jeol 1400plus transmission electron microscope at an accelerating voltage of $120 \mathrm{kV}$. Digital images were obtained using a Megaview mid mount digital camera (Olympus) or using a AMT XR16 bottom mid mount digital camera (AMTC). The sections were systematically analysed using AMTC software and several high and low magnifications were acquired.

\subsection{Bacteriological and parasitological examination}

Liver, spleen and lung samples were analysed using standard bacteriological methods. Parasitological examination of the intestine was carried out resourcing to direct wet mount, sedimentation and filtration techniques.

To investigate the presence of Enterobacteriacea the ID 32E (Biomerieux®) was used, while for non-Enterobacteriaceaethe API 20NE kit (Biomerieux®) was utilised. To test the presence of Streptococcus and Staphylococcus, the ID 32 STREPT (Biomerieux®) and the ID 32 STAPH kits (Biomerieux®) were used, respectively. The API CORYNE (Biomerieux®) kit was utilized for the identification of Corynebacteria and coryne-like organisms. To investigate the presence of Salmonella, peptone water and Rappaport Vassiliadis semi solid culture media were used. The agarose SMID2 and XLD culture media were utilized, whenever there was a suspicion of Salmonella. Other culture media 
used for bacterial identification in the samples included the MacConkey agar and the Blood agar culture media.

\subsection{Virological examination}

For nucleic acid extraction, fresh samples of liver and spleen were homogenised at $20 \%$ with phosphate buffered saline (PBS) and clarified at $3000 \mathrm{~g}$ for $5 \mathrm{~min}$. Total DNA and RNA were extracted from 200 $\mu$ l of the clarified supernatants, using the MagAttract 96 cador Pathogen Kit in a BioSprint 96 nucleic acid extractor (Qiagen, Hilden, Germany), according to the manufacturer's protocol.

All the animals were tested for rabbit haemorrhagic disease virus 2 (RHDV2) and MYXV by real time PCR systems described by Duarte et al (2015) [12] and Duarte et al (2014) [22], respectively.. The presence of LEHV-4 was investigated by using the PCR described by Jin et al (2008) [9]. A generalist nested PCR directed to the herpesviral DNA polymerase that allows the detection of herpesviruses of different subfamilies by Van Devanter et al. (1996) [16] was also used. Information regarding these methods is summarized in Table 2.

Amplifications were carried out in a Bio-Rad CFX96 ${ }^{\mathrm{TM}}$ Thermal Cycler (Bio-Rad Laboratories Srl, Redmond, USA), using the One Step RT-PCR kit (Qiagen, Hilden, Germany) for RHDV2, and the HighFidelity PCR Master Mix (Roche Diagnostics GmbH, Mannheim, Germany), for MYXV and herpesvirus detection, respectively. Amplifications were performed as described in Table 2.

\subsection{Sequencing analysis}

The PCR product was visualised in $2 \%$ horizontal electrophoresis agarose gel, purified using the NZYGelpure kit (NZYTECH), and directly sequenced using the ABI Prism BigDye Terminator v3.1 Cycle sequencing kit on a 3130 Genetic Analyser (Applied Biosystems, Foster City, CA, U.S.A). Nucleotide sequences were analysed and assembled into consensus sequences using the BioEdit version 7.2.5 software, and submitted to GenBank. Nucleotide sequences were translated using Mega X 10.1 software.

\subsection{Phylogenetic analysis}

Partial nucleotide (171bp) sequences, and the deduced amino acid sequences of the viral DNA polymerase gene were aligned using the Clustal $\mathrm{W}$ with gap opening penalty and a gap extend penalty of 30 and 15 , respectively. 
For both sets of data, evolutionary analyses were conducted in MEGA X [17]. The model for both phylogenies was selected by Model function (MEGA X).

The evolutionary history of 28 partial DNA polymerase nucleotide sequences of gammaherpesviruses was inferred by Maximum Likelihood. The Hasegawa-KishinoYano (HKY) model [18], which showed the lowest Bayesian Information Criterion (BIC) and Akaike Information Criterion corrected (AICC) values was used. A discrete Gamma distribution $(G)$ was used to model evolutionary rate differences among sites. The rate variation model allowed for some sites to be evolutionarily invariable (I).

The Le Gascuel model (2008) [19], Gamma distributed with invariant sites ( $\mathrm{G}+\mathrm{G}+\mathrm{l})$ was selected for the protein-based tree, according to BIC (5429.4) and AICC (5022.1) criteria. The analysis involved 37 amino acid sequences.

\subsection{Herpesvirus isolation}

Isolation of herpesvirus was attempted from organs of hares coinfected with MYXV and LeHV-5, namely from liver and spleen, penile and vulva samples. In addition, liver and spleen samples from two hares with single herpesvirus infection, were also used.

Samples were homogenized at $20 \%$ in phosphate-buffered saline containing penicillin, streptomycin and amphotericin B (antibiotic-antimycotic), used according to the manufacturer (Gibco, Life Technologies Corporation). Following centrifugation, the supernatant was filtered through a 0.45 - $\mu \mathrm{m}$-pore-size filter (Millipore Express) and used to inoculate sub $70 \%$ confluent Candrel R Feline Kidney (CRFK) epithelial cells (ATCCCCL-94), Vero cells (ATCC No. CRL-1986), Rabbit Kidney (RK13) cells (ATCC-CCL-37) and Hella cells (ATCC No. CRM-CCL-2)- RK13 cells grown in Eagle medium and the others in Dulbecco's modified Eagle's Media was supplemented with $10 \%$ foetal calf serum (Gibco), penicillin, streptomycin and amphotericin B (antibiotic-antimycotic used at $1: 100), 50 \mu \mathrm{g} / \mathrm{ml}$ gentamicin (Gibco). Cells were maintained at $37^{\circ} \mathrm{C}$ under humidified atmosphere with $5 \% \mathrm{CO}_{2}$ and observed daily for cytopathic effect (CPE) by phase contrast microscopy. Three passages were carried out. The supernatant and cell pellet of each passage were tested for the presence of herpesvirus by PCR [17].

\section{Results}

\subsection{Necropsy showed lesions compatible with herpesvirus infection in Iberian hares with Myxomatosis}

Overall, MYXV-positive hares revealed good body condition and, alongside typical myxomatosis lesions, necrosis of the genitalia was noticed in more than $70 \%$ of the hares 
studied. This lesion was more evident in males, affecting the penile glans, but was also observed in females inthe vulva. Other lesions observed in these hares included the presence of herpetic-like skin vesicles, uncommon in rabbits with myxomatosis.

Further investigation of the macroscopic lesions and histopathological patterns was carried out in hares co-infected with LeHV-5 and MYXV. At this time, we disclose the macroscopic and histopathological findings from two male hares found dead in November 2018 (\#38455/18, hereafter designated hare-1) and August 2019 (\#25456/19, hereafter designated hare-2).

Hare-1 presented with eyelids thickened by the accumulation of mucopurulent exudate and marked enlargement of the penis measuring $1.3 \times 1 \mathrm{~cm}$ in diameter (normal diameter is less than $0.5 \mathrm{~cm}$ ) and irregular surface (Figure 2 and Figure $2 \mathrm{~A}$ ) lined with light-yellow dry exudate.

At the necropsy, hare-2 showed ulcerated multinodular thickening of the eyelids and lips. Accumulation of mucopurulent exudate in both eyes was also registered and a small vesicle was present in the lower lip (Figure 3).

\subsection{Histopathology}

The dermis of hare-1 showed fusiform or stellate mesenchymal cell proliferation, surrounded by abundant extracellular matrix, scattered infiltration by lymphocytes and macrophages, and small aggregates of heterophiles, consistent with myxomatosis.

The penile epithelium of this hare was mostly necrotic and replaced by a thick band of necrotic cells, heterophils and red blood cells (Figure 2).

Severe heterophile infiltrations of the stroma, in either a diffuse pattern or multifocal aggregates, were also seen. In the stroma, there was also proliferation of pleomorphic spindle cells, with some nuclei almost filled with slightly eosinophilic inclusion bodies (Cowdry type A inclusions) (Figure 4), suggesting a nuclear replicating virus. These lesions, unexpected in myxomatosis, are compatible with herpesvirus.

In the skin of hare-2, a ballooning degeneration of keratinocytes was registered. Coalescent intra-epidermal and subepidermal vesicopustules (Figure 5) filled with fibrin and necrotic cells debris and multifocal detachment of the eyelids, lips and foreskin epidermis were seen. In the underlying dermis, multifocal haemorrhages, intense infiltration by heterophils and necrotic cells with accumulation of chromatin debris were present (Figure 5).

Below the dermis, accumulation of myxoid tissue with pleomorphic spindle cells, some of which showing rounded or oval and slightly eosinophilic intranuclear inclusion bodies, 
was observed (Figure 6). An infiltrate of mononucleated inflammatory cells and heterophils was present in skeletal muscle tissue.

\subsection{Electron microscopy}

Samples from hare-1 and hare-2 were further processed and analysed for TEM allowing the confirmation of the presence of herpesvirus in different tissues.

In the penile soft tissue of hare-1, spherical virions, with structure and dimensions compatible with herpesviruses, comprising an inner core packed into an icosahedral capsid, were observed in the nucleus of stromal cells (Figure 7), indicating nuclear replication (Figure $7 \mathrm{~b}$ ), which is an attribute of herpesviruses. The viral capsid contained a relatively small, asymmetrical, electron-dense region that probably represents the condensed DNA core. In this animal, also positive to myxomatosis, no MYXV particles were found in the samples processed.

\subsection{Virological, bacteriological and parasitological results}

None of the 38 hares investigated in this study tested positive to RHDV, RHDV2 or LEHV-4. Fifty percent of the hares were positive to LeHV-5, of which $68.4 \%$ (13/19) were also positive to MYXV.

Herpesvirus-DNA was also detected by PCR in the liver, spleen and lung samples of $41.2 \%(7 / 17)$ of the apparently healthy hunted hares that tested negative for MYXV. From this group of hares, no genitalia/skin samples were available for histopathology.

Six hares showed doubtful results from which four were MYXV-negative. Parasitological and bacteriological examinations did not reveal any infections that could justify the death of these animals.

\subsection{Molecular characterisation of Iberian hare herpesvirus}

For $50 \%$ of the animals (19/38), an amplicon 225 bp-long, compatible with herpesvirus, was obtained in the pan-herpesvirus PCR [17]. For six hare samples only a weak band was generated, therefore were not considered for further analysis. The presence of herpesvirus was confirmed by sequencing analysis in 16 hares. For 11 of these amplicons, the nucleotide sequences obtained were independently edited to remove the primer targeting sequences and assembled. The consensus sequences (171 bp) showed $100 \%$ similarity to each other.

Blast analysis (28.02.2020) of the sequences confirmed homology with herpesvirus DNA polymerase coding sequence. 
Though with a low query cover of $48 \%, 78.31 \%$ of similarity was observed with a Phocid herpesvirus 2 (NC_043062.1) and 77.11\% with Megabat gammaherpesvirus (LC268920.1) and a Harp seal herpesvirus (KP136799.1).

Regarding the amino acid sequences, when compared with others from herpesvirus available in the GenBank database (28.02.2020), bat herpesviruses (ALH21079.1, ALH21081.1 and ALH21071.1) showed $52.63 \%$ identity over a query cover of $100 \%$. Similarity was also found with Equid gammaherpesvirus 5 (AAD30141.1) showing $72.50 \%$ of identity and $62 \%$ of query cover, and with Asinine herpesvirus 4.1 (AAL14768.1), displaying $62 \%$ of identity over a query cover of $82 \%$.

Five of the obtained sequences were submitted to the GenBank (MN557129-33).

\subsection{Phylogenetic analysis}

It has been shown that, despite reduced, the region amplified by the nested PCR has discriminatory power to allow phylogenetic inferences [16]. To investigate the phylogenetic relationship of the Iberian hare herpesviruses found in this study (represented by sequence MN557129), with other members of the Herpesviridae family, a set of 37 DNA polymerase protein sequences from alpha-, beta- and gammaherpesviruses, obtained from GenBank, were edited to span a 54 to 59 aaresidue region comprising the homologous regions encoded by sequence MN557129. Analysis of protein sequences by unrooted Maximum Likelihood method and LG+G+l model [19] showed that the herpesvirus sequence from Lepus granatensis groups within the gammaherpesvirus cluster (Figure 8). Sequence MN557129 appears to share a common ancestor with gammaherpesviruses from Scotophilus kuhlii (KR261869.1, ALH21071.1 and ALH21079.1), a small insectivore bat native of Asia and India, as well as with some rodent herpesviruses (KT591396.1, KT591394.1 and others) (Figure 8). To refine the phylogenetic inference within gammahespesviruses, the nucleotide variability among this group was explored using a set of 28 gammaherpesviruses nucleotide sequences from orders Carnivora, Chiroptera, Rodentia, Artiodactyla, Lagomorpha, Perissodactyla and Primates (Figure 9). The tree with the highest log likelihood $(-3335,05)$ is shown in Figure 9. The accession numbers of the original sequences from which the DNA Polymerase 159-178 nt long sequences were edited, are indicated in the respective legend.

This phylogenetic analysis confirmed that the leporid herpesvirus under study is more closely related with gammaherpesviruses from Scotophilus kuilii of unclassified genera. In this tree, no polytomies were observed. 
Despite more information on the genome of this herpesvirus is required, this preliminary analysis suggest that it may represent a specific replicating lineage. In accordance, we propose to name this virus Leporid gammaherpesvirus 5 (LeHV-5), following the rabbit alphaherpesvirus 4 (LeHV-4), the only leporid herpesvirus recognised so far as a species by the ICTV.

\subsection{Isolation of the viruses in cell cultures}

The difficulties found in viral isolation in CRFK, Vero, RK13 and Hella cells may be explained by the fact that LeHV- 5 is a gammaherpesvirus.

Despite LeHV-5 seems unable to multiply in human (Hela) and primate (Vero) cells, given the zoonotic potential of some animal herpesviruses, as the case of the cercopithecine alphaherpesvirus 1 [20] and the murine gamma herpesvirus 68 [21], all isolation attempts were carried out in BSL-2 conditions.

\section{Discussion and Conclusion}

This study describes the detection of the first herpesvirus (Leporid gammaherpesvirus 5 ) in the genus Lepus that, according to the phylogenetic analysis, is more similar to bats and rodent gammaherpesviruses.

Viral isolation was not successful in RK13, CRFK or Vero cells. The difficulty in growing the virus in vitro, an important step towards its characterisation, may be a consequence of the co-infection with MYXV. The greater ease in the multiplication of MYXV, which grows in many cell cultures[22,23], may have hampered herpesvirus isolation. Moreover, wild animal samples are frequently somewhat autolysed and usually frozen before reaching the laboratory, which may lead to herpesvirus inactivation. The complexity in isolating genital gammaherpesvirus in cell culture was also referred by [24]. The lack of cell cultures from Lepus species may pose further challenges.

During our investigation, we observed necrosis of the genitals and herpetic-like vesicles in the lips of hares co-infected with LeHV-5 and MYXV, which were attributed to herpesvirus. The presence of LeHV-5 in the penile of hare- 1 was confirmed by PCR and TEM, as shown in Figure 7. Herpesvirus particles were also visualised in epithelial and stroma cells of the eyelid of hare-2.

Notwithstanding the sampling limitation, the fact that macroscopic lesions were only seen in animals with myxomatosis, suggests that MYXV may play a role on herpesvirus replication and/or reactivation by compromising the immune response of the host, leading to the subsequent development of clinical disease with exuberant lesions. Immunosuppression facilitates herpesvirus infections and virus reactivation and it was 
demonstrated that certain MYXV proteins, such as Serp-1, have strong immune suppressing effects[23]. MYXV infection may hence represent a stress and/or immunosuppressive triggering factor for herpesvirus infection. It is known that stress, disease and other factors such as extreme temperatures can lead to the resurgence of herpesviruses in other species[25]. It was observed that depressed T-cell immune function reduces the quality of immune surveillance resulting in the increase of viral activity [26].

Herpesviruses generally follow one of three distinct strategies[26] within the host, namely i) latency with occasional re-emergence, ii) hit-and-run' approach and iii) slow-and-low' tactic [26].In the case of LeHV-5, because it affects wildlife, specimens are mainly animals found dead or moribund, limiting the conclusions on the strategy of the virus.

In addition, herpesviruses are frequently found either in the absence of clinical signs or in association with very diverse clinical signs[27].This fact muddles the understanding of the true role and relative contribution of many herpesviruses in the courses of certain diseases, especially with regards to wild species that are often exposed to, and infected by, many pathogens. On the other hand, animal experimentation is complicated by the absence of available specific pathogen free (SPF) specimens, and by the difficulties in keeping hares in captivity, limiting cause-effect experiments. Moreover, during latency, herpesviruses may not be detected by current methods as it is the case of gammaherpesvirus in horses, resulting in an underestimated prevalence in the populations[27],[28]. Reports indicate that equine herpesvirus 2 (EHV-2) can be detected in immunocompetent animals in the absence of signs of disease (revised on Marenzoni et al., 2015), meaning that healthy animals can be a potentially source of viral transmission.

According to our study, based on viral DNA amplification, around half of animals tested (63\% symptomatic and $37 \%$ asymptomatic) were positive for LeHV-5. However, this value may be an underestimation given that the tropism of LeHV-5 is still unknown, and consequently the tissue samples used for diagnosis may have been inadequate. Thus, we cannot assure that PCR negative animals were not false negatives.

The fact that herpetic lesions were not observed in young, could mean that if the acquisition of LeHV-5 occurs at an early age, primary infection takes place with mild or no symptoms. In the absence of an unbalancing triggering factor such as MYXV infection, LeHV-5 may successfully establish a long-term relationship with the hare host, with subclinical disease and transient viremia. This would explain the detection of herpesvirus DNA in apparently healthy hares.

Interestingly, the gammaherpesvirus identified in external genitalia of the investigated hares was not associated with the development of papillary lesions as in other genital 
gammaherpesviruses' infections[24]. However, given that hunters, hunting managers and landowners have the opinion that the reproduction of the Iberian hare has been declining in recent years, it is important to clarify if this reduction is also associated with the emergence or circulation of LeHV-5. Other important concern is the potential production of oncogenic proteins by this herpesvirus.

According to our findings, genital herpesvirus may have a critical effect on hares' fertility and reproduction as well as in their survival. Hence, it is crucial to evaluate and understand the extent to which MYXV plays a role in the infection/reactivation of herpesvirus, as well as the putative role of herpesvirus in favouring infection of hares by MYXV or aggravating the severity of myxomatosis clinical forms.

The virological results obtained in this study also disclosed the infection of apparently healthy hares by LeHV-5, suggesting the possible circulation of this virus in the wild populations in a subclinical form. Because herpesvirus-DNA was detected in internal organs (liver and spleen), this asymptomatic infection may be systemic.

Although the Iberian hare populations are still considered stable, no census is available for the populations in Portugal. Presently, we continue monitoring apparently healthy and MYXV-positive hares in mainland Portugal to determine the extent of the geographic distribution of LeHV-5 among the wild hare populations, and the putative association of herpesviruses with the virulence of the recently emerged hare myxoma virus.

It is of paramount importance to evaluate the geographical distribution of the virus in the hare populations, the real extent and severity of the lesions induced in hares by LeHV5 , the persistence and latency of herpesvirus in the wild populations and the LEHV-5MYXV associated pathology in order to predict the consequences of the LEHV-5 infection at population level and to evaluate its importance in the future of this iconic species. 


\section{References}

1. Soriguer A. Lepus granatensis, Granada Hare. 2019;8235.

2. Palacios F. On the taxonomic status of the genus Lepus in Spain. Acta Zool. 1983;Fennica 17: 27-30.

3. Fenner F, Fantini B. History of Myxomatosis - an Experiment in Evolution. CABI. Biological Control of Vertebrate Pests. CABI. New York, USA; 1999.

4. Barlow A, Lawrence K, Everest D, Dastjerdi A, Finnegan C, Steinbach F. Confirmation of myxomatosis in a European brown hare in Great Britain. Vet Rec. 2014;175: 75-76. doi:10.1136/vr.g4621

5. Collins JJ. Myxomatosis in the common hare. Ir Vet J. 1955;9, 268.

6. Wibbelt G. Infectious Diseases in European Brown Hare ( Lepus europaeus ). 2014. doi:10.2461/wbp.2005.1.11

7. Bocanegra IG, Dalton KP, Gómez JC. First outbreak of myxomatosis in Iberian hares ( Lepus granatensis ). 2019; 1-5. doi:10.1111/tbed.13289

8. OIE. Myxomatosis, Portugal. 2018. Available:

https://www.oie.int/wahis_2/public/wahid.php/Reviewreport/Review?page_refer= MapFullEventReport\&reportid=28628

9. Jin L, Löhr C V., Vanarsdall AL, Baker RJ, Moerdyk-Schauwecker M, Levine C, et al. Characterization of a novel alphaherpesvirus associated with fatal infections of domestic rabbits. Virology. 2008;378: 13-20. doi:10.1016/j.virol.2008.05.003

10. Barthold SW, Griffey SM, Percy DH. Rabbit. 4 th. Pathology of Laboratory Rodents and Rabbits. 4 th. 2016. p. 258.

11. C. Brown J, W. Newcomb W. Herpesvirus Capsid Assembly : Insights from Structural Analysis. Curr Opin Virol. 2011;1: 142-149.

doi:10.1016/j.coviro.2011.06.003. Herpesvirus

12. Davison AJ, Richard E, Bernhard E, Gary HS, Duncan MJ, Anthony MC, et al. The order of Herpesvirales. Arch Virol. 2009;154: 171-177. doi:10.1007/s00705008-0278-4.The

13. Sunohara-Neilson JR, Brash M, Carman S, Nagy É, Turner P V. Experimental infection of New Zealand white rabbits (Oryctolagus cuniculi) with leporid herpesvirus 4. Comp Med. 2013;63: 422-431.

14. David M. Knipe PM. Fields Virology. 6th Editio. In: Williams L, Wilkins, editors. Fields Virology. 6th Editio. Philadelphia, PA, USA; 2013.

15. Graham L, Orenstein JM. Processing tissue and cells for transmission electron microscopy in diagnostic pathology and research. Nat Protoc. 2007;2: 2439_ 
2450. doi:10.1038/nprot.2007.304

16. Devanter DRVAN, Warrener P, Bennett L, Schultz ER, Coulter S, Garber RL, et al. Detection and Analysis of Diverse Herpesviral Species by Consensus Primer PCR. 1996;34: 1666-1671.

17. Kumar S, Stecher G, Li M, Knyaz C, Tamura K. MEGA X: Molecular Evolutionary Genetics Analysis across computing platforms. Molecular Biology and Evolution. 2018.

18. M. H, H. K, T Y. Dating the human-ape split by a molecular clock of mitochondrial DNA. J Mol Evol. 1985;22: 160-174.

19. Le SQ, Gascuel O. An Improved General Amino Acid Replacement Matrix. Mol Biol Evol. 2008;25: 1307-1320.

20. Huff JL, Barry PA. Infection in Humans and Macaques : Potential for Zoonotic Disease. Emerg Infect Dis •. 2003;9.

21. Hricová M, Mistríková J. Murine gammaherpesvirus 68 serum antibodies in general human population. Acta Virol. 2007;51: 283-287.

22. Fenner F, Ratcliffe FN. Myxomatosis. Cambridge Univ Press London, UK. 1965.

23. Spiesschaert B, Mcfadden G, Hermans K, Nauwynck H, Walle GR Van De. The current status and future directions of myxoma virus, a master in immune evasion. Vet Res. 2011;42: 76. doi:10.1186/1297-9716-42-76

24. Saliki JT, Cooper EJ, Rotstein DS, Caseltine SL, Pabst D., McLellan WA, et al. A Novel Gammaherpesvirus Associated with Genital Lesions in a Blainville's Beaked Whale (Mesoplodon densirostris). J Wildl Dis. 2006;42: 142-148.

25. Izumi Y, Tsuduku S, Murakami K, Tsuboi T, Konishi M, Haritani M, et al. Characterization of bovine herpesvirus type 4 isolated from cattle with mastitis and subclinical infection by the virus among cattle. J Vet Med Sci. 2006;68: 189193. doi:10.1292/jvms.68.189

26. Grinde B. Herpesviruses: latency and reactivation ? viral strategies and host response. J Oral Microbiol. 2013;5: 125-136. doi:10.3402/jom.v5i0.22766

27. Marenzoni M, Stefanetti V, Danzetta ML, Timoney PJ. Gammaherpesvirus infections in equids: a review. Vet Med Res Reports. 2015; 91. doi:10.2147/vmrr.s39473

28. Williams KJ, Robinson NE, Lim A, Brandenberger C, Maes R, Behan A, et al. Experimental Induction of Pulmonary Fibrosis in Horses with the Gammaherpesvirus Equine Herpesvirus 5. PLoS One. 2013;8: 1-15. doi:10.1371/journal.pone.0077754

29. Zygraich N, Berge E. Experimental Infection of Rabbits and Monkeys with Herpesvirus cuniculi. 1972;13: 241-244. 
30. Hesselton RM, Yang WC, Medveczky P, Sullivan JL. Pathogenesis of Herpesvirus sylvilagus infection in cottontail rabbits. Am J Pathol. 1988;133: 639-647.

31. Akatsuka K, Nii S. Tubular Structures Detected in the Nuclei of Human Embryonal Lung Fibroblasts Infected with Human Cytomegalovirus Kazuya AKATSUKA and Shiro NII * of Virology , Okayama Okayama ( Accepted for publication, December Various viruses with icosahedral capsids. Microbiollmmunol. 1986;30: 289-296.

32. Hinze HC. New Member of the Herpesvirus Group Isolated from Wild Cottontail Rabbits. 1971;3: 350-354.

33. Brash ML, Nagy É, Pei Y, Carman S, Emery S, Smith AE, et al. Acute hemorrhagic and necrotizing pneumonia, splenitis, and dermatitis in a pet rabbit caused by a novel herpesvirus (leporid herpesvirus-4). Can Vet J. 2010;51: 1383-1386.

34. Roizman B, Pellett P. The family Herpesviridae: a brief introduction. 4th ed. In: Knipe DM, Howley P., editors. 4th ed. Philadelphia: Lippincott Williams \& Wilkins; 2001. pp. 2381-2397pp.

35. Duarte MD, Carvalho CL, Barros SC, Henriques AM, Ramos F, Fagulha T, et al. A real time Taqman RT-PCR for the detection of rabbit hemorrhagic disease virus 2 (RHDV2). J Virol Methods. 2015;219: 90-95. doi:10.1016/j.jviromet.2015.03.017

36. Duarte MD, Barros SC, Henriques AM, Fagulha MT, Ramos F, Luís T, et al. Development and validation of a real time PCR for the detection of myxoma virus based on the diploid gene M000 . 5L / R. J Virol Methods. 2014;196: 219224. doi:10.1016/j.jviromet.2013.11.014 


\section{Captions}

Table 1. Summary of the characteristics of the four herpesviruses identified in leporids.

Table 2. Molecular methods used for the detection of RHDV2 (Duarte et al, 2015), MYXV (Duarte et al, 2014), LeHV 4 [9] and a wide variety of herpesviral genomes from human and animal herpesviruses (Van Devanter, 1996).

Figure 1. Map of Portugal showing the geographic origin of the 38 LeHV-5 positive hares over the total sampling per District. White coloured Districts were not sampled. Darker shades correspond to higher positivity.

Figure 2. Penis of hare-1. 2- H\&E staining showing several necrotic areas in the epithelium (E) and multifocal heterophils aggregates in the stromal tissue $(\mathrm{H})$. Corpus cavernosum (CC); penile uretra (U). $4 \mathrm{x}$.

$2 \mathrm{~A}$ - Cross section of penis after fixation- exuberant thickening of the penis.

Figure 3. Hare-2 - Oedema of lips and nose with ulcerated nodules in the upper lip. A vesicle can be seen in the lower lip (arrow)

Figure 4. Penis of hare-1. Intranuclear inclusion bodies in mesenchymal cells (arrows) and moderate to severe infiltration by heterophils, H\&E, 400x.

Figure 5. Lip of hare-2. Intraepidermal and subepidermal vesicopustules (V) that appear as "empty spaces" between the dermis and the epidermis, causing the detachment of the epidermis; mixomatous tissue (M) in the dermis characterized by abundant extracellular matrix pulling apart the fibroblasts; microhemorrhages $(H)$ in the uppermost layer of the dermis;. H\&E, 40x

Figure 6. Lip of hare-2. Oedema and inflammatory cell infiltration with signs of necrosis. An intranuclear inclusion body in a mesenchymal cell can be seen (arrow). H\&E, 400x.

Figure 7. Electron micrographs of penile soft tissue of hare-1. a- Overview of a virusinfected cell ( $N$, nucleus; $n$, nucleolus; nm, nuclear membrane; Cy, cytoplasm; arrowhead, viral particles); b- Naked capsids seen in areas of euchromatin in the nucleolus. c- DNA-loaded capsids close to the nuclear membrane in the process of budding into the perinuclear space; $\mathbf{d}$ Tegument assembly in the cytoplasm of the host 
cell. Photos obtained in a transmission electron microscope Hitachi $\mathrm{H}-7000$ using iTEM software and Megaview III mid-mounted camera.

Figure 8. Phylogenetic analysis based on 37 partial DNA Polymerase amino acid sequences of herpesviruses from several vertebrate species. The access number of the nucleotide sequences from which the amino acid sequences were deduced are given. The tree with the highest log likelihood (-2432.55) is shown. The $L G+G+I$ model considering 5 categories, $[+\mathrm{G}]$ parameter of 0,9929 and $[+\mathrm{l}]$ of $11,47 \%$ sites was used. The tree is drawn to scale, with branch lengths measured in the number of substitutions per site. There were a total of 60 positions in the final dataset. Robustness of the tree nodes was assessed by bootstrapping 1000 times. Only bootstrap values $\geq 70$ are shown. The evolutionary analyses were conducted in MEGA X [17] and the phylogenetic tree was edited in the Figtree software version 1.4.0.

Figure 9. Phylogenetic tree based on 28 partial nucleotide sequences of several gammaherpesviruses inferred by using the Maximum Likelihood method. The tree with the highest log likelihood $(-3335,05.01)$ is shown. The $H K Y+G+I$ model [18] considering 5 categories, [+G] parameter of 3,2029 and [+l] of $10,93 \%$ sites was used. There were a total of 183 positions in the final dataset. The tree is drawn to scale, with branch lengths measured in the number of substitutions per site. Robustness of the tree nodes was assessed by bootstrapping 1000 times. Only bootstrap values $\geq 70$ are shown. The evolutionary analyses were conducted in MEGA X [17] and the phylogenetic tree was edited in the Figtree software version 1.4.0. 
Table 1

\begin{tabular}{|c|c|c|c|c|c|c|}
\hline Type & Subfamily & $\begin{array}{c}\text { Species } \\
\text { (ITCV classification) }\end{array}$ & Common Name & Host & Physiopathology & Isolation \\
\hline LeHV-1 & Y & Not attributed ${ }^{a}$ & Cottontail herpesvirus & Sylvilagus floridanus & & $\begin{array}{l}\text { Isolated from primary kidney cells cultures of Sylvilagus } \\
\text { floridanus [13]. } \\
\text { No report of disease in domestic rabbits, since Oryctolagus } \\
\text { cuniculus is not infected [10]. }\end{array}$ \\
\hline LeHV-2 & Y & Not attributed ${ }^{a}$ & Herpesvirus cuniculi & Oryctolagus cuniculus & $\begin{array}{l}\text { Some evidences of a subclinical } \\
\text { encephalitis in infected New Zealand } \\
\text { white rabbits [29]. }\end{array}$ & $\begin{array}{l}\text { Isolated in } 1968 \text { from kidneys of apparently healthy } \\
\text { Sylvilagus floridanus [30]. } \\
\text { Oryctolagus cuniculus is the natural host where infection is } \\
\text { asymptomatic[31] }\end{array}$ \\
\hline LeHV-3 & Y & Not attributed ${ }^{a}$ & Herpesvirus sylvilagus & Sylvilagus floridanus & $\begin{array}{l}\text { Lymphoproliferative disease and } \\
\text { tumour-like lesions in the lymph } \\
\text { nodes, kidney, spleen, and liver } \\
{[30,32] .}\end{array}$ & $\begin{array}{l}\text { Isolated from primary kidney cells cultures of Sylvilagus } \\
\text { floridanus [13]. } \\
\text { Oryctolagus cuniculus is not infected } \\
\text { Not isolated in WI-38, HeLa, Chang's conjunctiva, human } \\
\text { amnion (FL), green monkey kidney (Vero), primary rhesus } \\
\text { monkey kidney, primary hamster kidney, BHK-21, primary } \\
\text { mouse embryo, and primary chick embryo } \\
\text { [32].[32][32][32][32][32][32] } \\
\text { Isolated in DRK-3 cells [32]. } \\
\text { CPE appear after 10-15 days of inoculation. Infected cells } \\
\text { show focal areas of round and distorted cells, and in 1-2 } \\
\text { days, emerged syncytial masses containing } 50 \text { or more } \\
\text { nuclei [30]. } \\
\text { H\&E coloration show typical type A intranuclear inclusions in } \\
\text { the infected cells. Complete cell destruction occurred after a } \\
5 \text { to 7-days period [30]. }\end{array}$ \\
\hline LeHV-4 & $\alpha$ & Attributed $^{b}$ & & Oryctolagus cuniculus & $\begin{array}{l}\text { Lethargy, anorexia, conjunctivitis, } \\
\text { fever, and abortion. Haemorrhagic } \\
\text { dermatitis, splenic necrosis, hepatic } \\
\text { necrosis, and multifocal pulmonary } \\
\text { haemorrhage and oedema. Distinctive } \\
\text { glassy eosinophilic herpetic } \\
\text { intranuclear inclusion bodies were } \\
\text { observed in the skin fibroblasts? And } \\
\text { mesenchymal cells of the spleen and } \\
\text { lung }[9,33] \text {. }\end{array}$ & $\begin{array}{l}\text { Isolated in rabbit skin (RS), RK13 and Vero cells [9]. CPE } \\
\text { characterized by syncytium formation, cell enlargement, and } \\
\text { cell lysis, similar to human herpesvirus type } 1 \text { (HHV-1). Jin et } \\
\text { al. [9] verified that in rabbits inoculated with LHV-4, the } \\
\text { appendix, sciatic nerve, kidney, adrenal gland, and many } \\
\text { other organs were positive for the virus at the } 5 \text {-days post } \\
\text { infection(dpi), while at the } 14 \text { dpi only trigeminal ganglia eye } \\
\text { and tonsil were positive. }\end{array}$ \\
\hline LeHV-5 & y & Not attributed & Iberian hare herpesvirus & Lepus granatensis & Described in the results of this work & \\
\hline
\end{tabular}

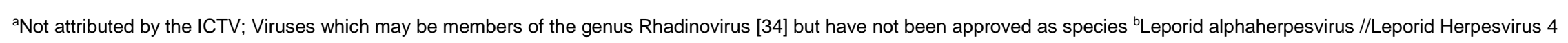


Table 2

\begin{tabular}{|c|c|c|c|c|}
\hline Primer & Sequence (5'-3') & Amplicon size (bp) & Amplification conditions & Reference \\
\hline RHDV2-F & TGGAACTTGGCTTGAGTGTTGA & \multirow{3}{*}{127} & $50 \cdot \mathrm{C}-45 \mathrm{~min}$ & \multirow{3}{*}{ [35] } \\
\hline RHDV2-R & ACAAGCGTGCTTGTGGACGG & & $50 \times\left(95^{\circ} \mathrm{C}-15 \mathrm{~s}\right.$ & \\
\hline RHDV2-Probe & [FAM]-TGTCAGAACTTGTTGACATCCGCCC-[TAMRA] & & $72 \cdot \mathrm{C}-30 \mathrm{~s})$ & \\
\hline M000.5R/L-F & CGACGTAGATTTATCGTATACC & \multirow{3}{*}{125} & $95 \cdot \mathrm{C}-10 \mathrm{~min}$ & \multirow{3}{*}[36]{} \\
\hline M000.5R/L-R & GTCTGTCTATGTATTCTATCTCC4 & & $\begin{array}{r}45 X\left(95^{\circ} \mathrm{C}-30 \mathrm{~s}\right. \\
50^{\circ} \mathrm{C}-30 \mathrm{~s}\end{array}$ & \\
\hline MYXV-probe & [FAM]-TCTATGTCTGCCCGAGGATAGA-[TAMRA] & & $60 \cdot \mathrm{C}-30 \mathrm{~s})$ & \\
\hline LeHV-4 F1F & \multirow{3}{*}{$\begin{array}{l}\text { ATGACGCCCACCAACGTCTC } \\
\text { GCACAGTGTGTGTTAGACG } \\
\text { TGTGGCCAAGAACAACGATA }\end{array}$} & \multirow{6}{*}{$\begin{array}{c}1617 \\
1162 \\
945\end{array}$} & \multirow{6}{*}{$\begin{array}{r}95^{\circ} \mathrm{C}-10 \mathrm{~min} \\
35 \times\left(95^{\circ}-15 \mathrm{~s}\right. \\
54^{\circ} \mathrm{C}-20 \mathrm{~s} \\
\left.72^{\circ} \mathrm{C}-3 \mathrm{~min}\right) \\
72^{\circ} \mathrm{C}-10 \mathrm{~min}\end{array}$} & \multirow{6}{*}{ [33] } \\
\hline LeHV-4 F2F & & & & \\
\hline LeHV-4 F3F & & & & \\
\hline LeHV-4 F1R & CATAGACCGTAGGCGGTTC & & & \\
\hline LeHV-4 F2R & ACGTGAACAGGAACCGGTAG & & & \\
\hline LeHV-4 F3R & CTAGAGGTCGTTCACCACCG & & & \\
\hline DFA ( $F 1^{\text {st }}$ round $)$ & GAYT TYGCNAGYYTNTAYCC & \multirow{5}{*}{215 to 315} & \multirow{5}{*}{$\begin{array}{r}94^{\circ} \mathrm{C}-10 \mathrm{~min} \\
35 \times\left(94^{\circ} \mathrm{C}-60 \mathrm{~s}\right. \\
46^{\circ} \mathrm{C}-60 \mathrm{~s} \\
\left.72^{\circ} \mathrm{C}-3 \mathrm{~min}\right)\end{array}$} & \multirow{3}{*}{ [16] } \\
\hline ILT (F1 $1^{\text {st }}$ round $)$ & TCCTGGACAAGCAGCARNYS GCNMTNAA & & & \\
\hline TGV (F1'st round) & TGTAACTCGGTGTAYGGNTTYACNGGNGT & & & \\
\hline KG1 (R $2^{\text {nd }}$ round) & GTCTTGCTCACC AGNTCNACNCCYTT & & & \\
\hline IYG (R $2^{\text {nd }}$ round $)$ & CACAGAGTCCGTRTCNCCRTADAT & & & \\
\hline
\end{tabular}


bioRxiv preprint doi: https://doi.org/10.1101/2020.01.21.913723; this version posted March 21, 2020. The copyright holder for this preprint (which was not certified by peer review) is the author/funder. All rights reserved. No reuse allowed without permission.

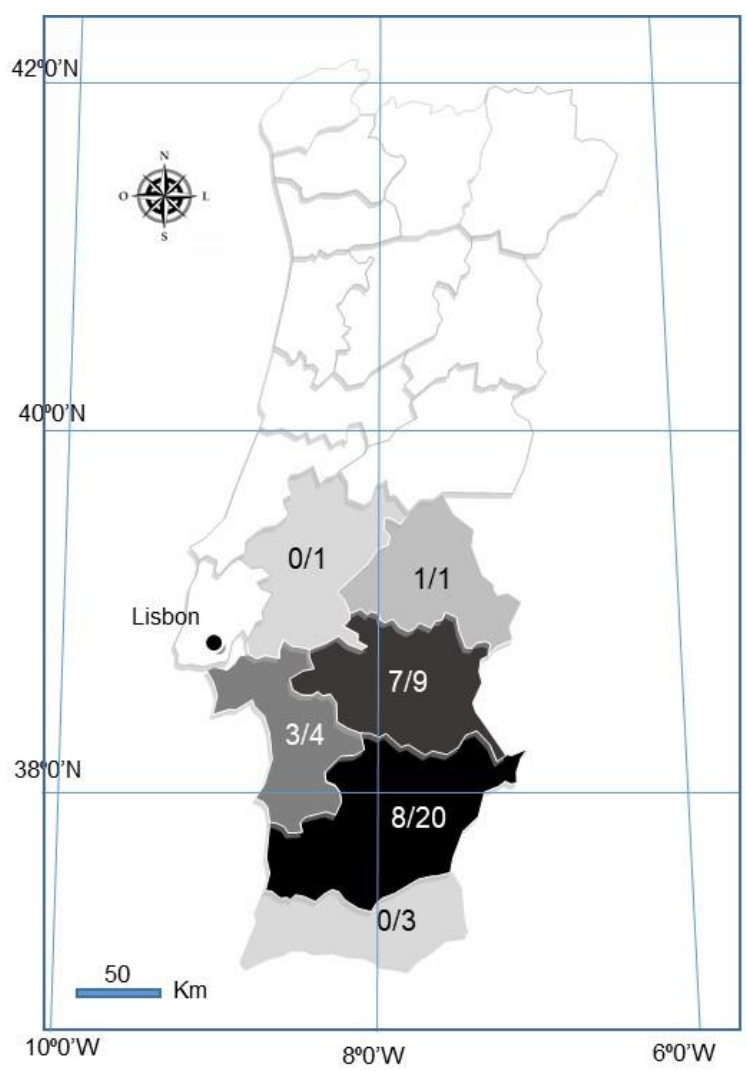

Figure 1 
bioRxiv preprint doi: https://doi.org/10.1101/2020.01.21.913723; this version posted March 21, 2020. The copyright holder for this preprint (which was not certified by peer review) is the author/funder. All rights reserved. No reuse allowed without permission.

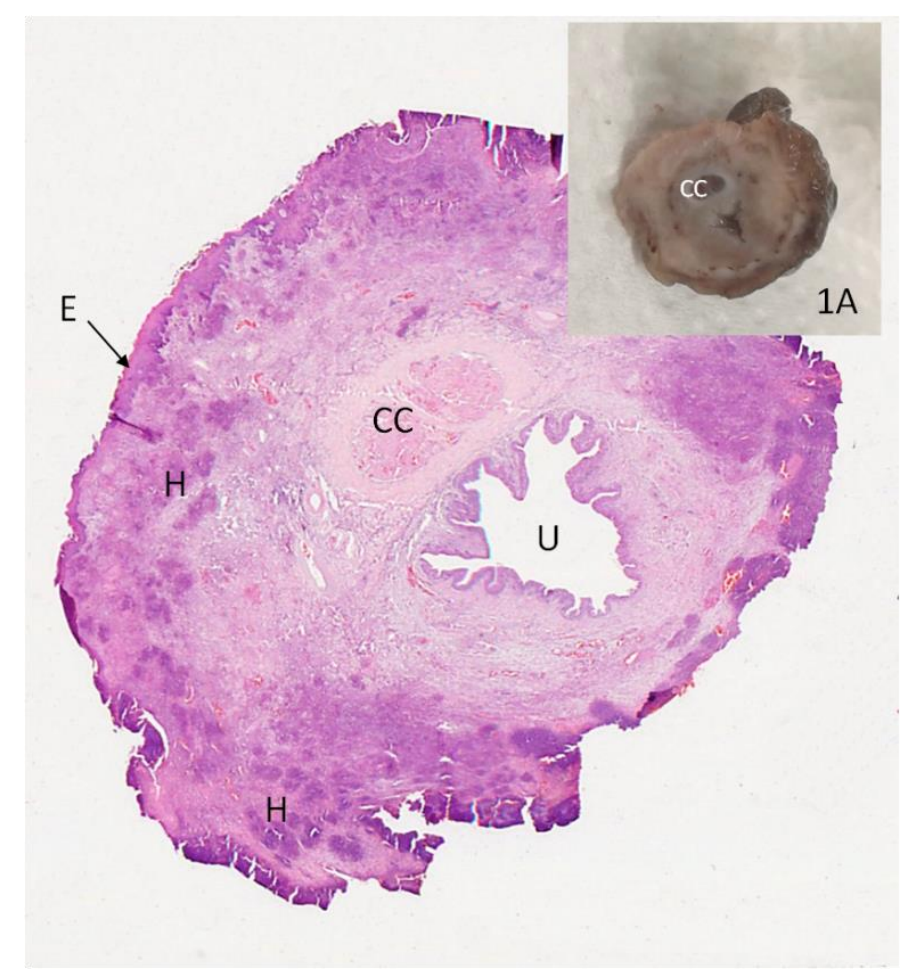

Figure 2 
bioRxiv preprint doi: https://doi.org/10.1101/2020.01.21.913723; this version posted March 21, 2020. The copyright holder for this preprint (which was not certified by peer review) is the author/funder. All rights reserved. No reuse allowed without permission.

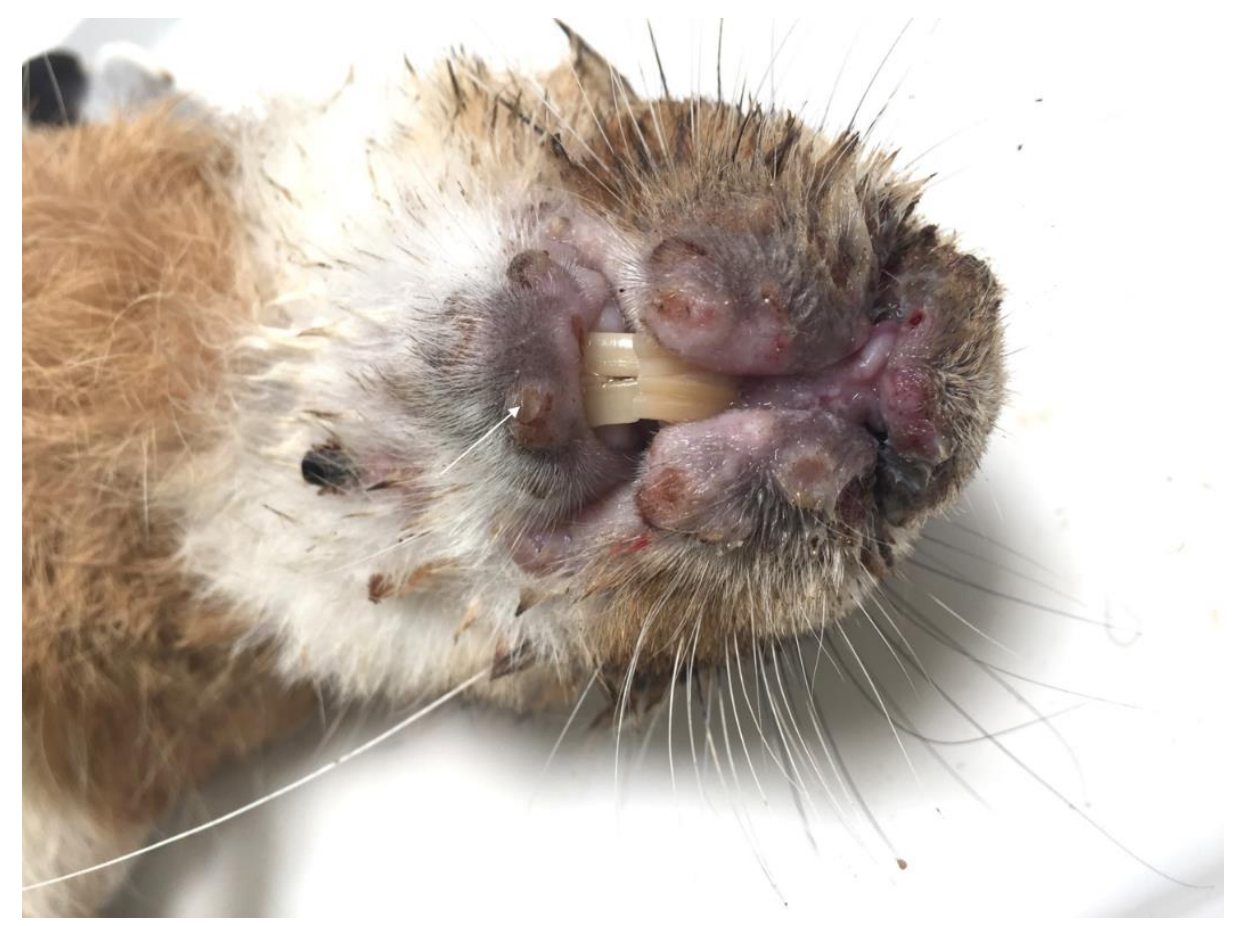

Figure 3 
bioRxiv preprint doi: https://doi.org/10.1101/2020.01.21.913723; this version posted March 21, 2020. The copyright holder for this preprint (which was not certified by peer review) is the author/funder. All rights reserved. No reuse allowed without permission.

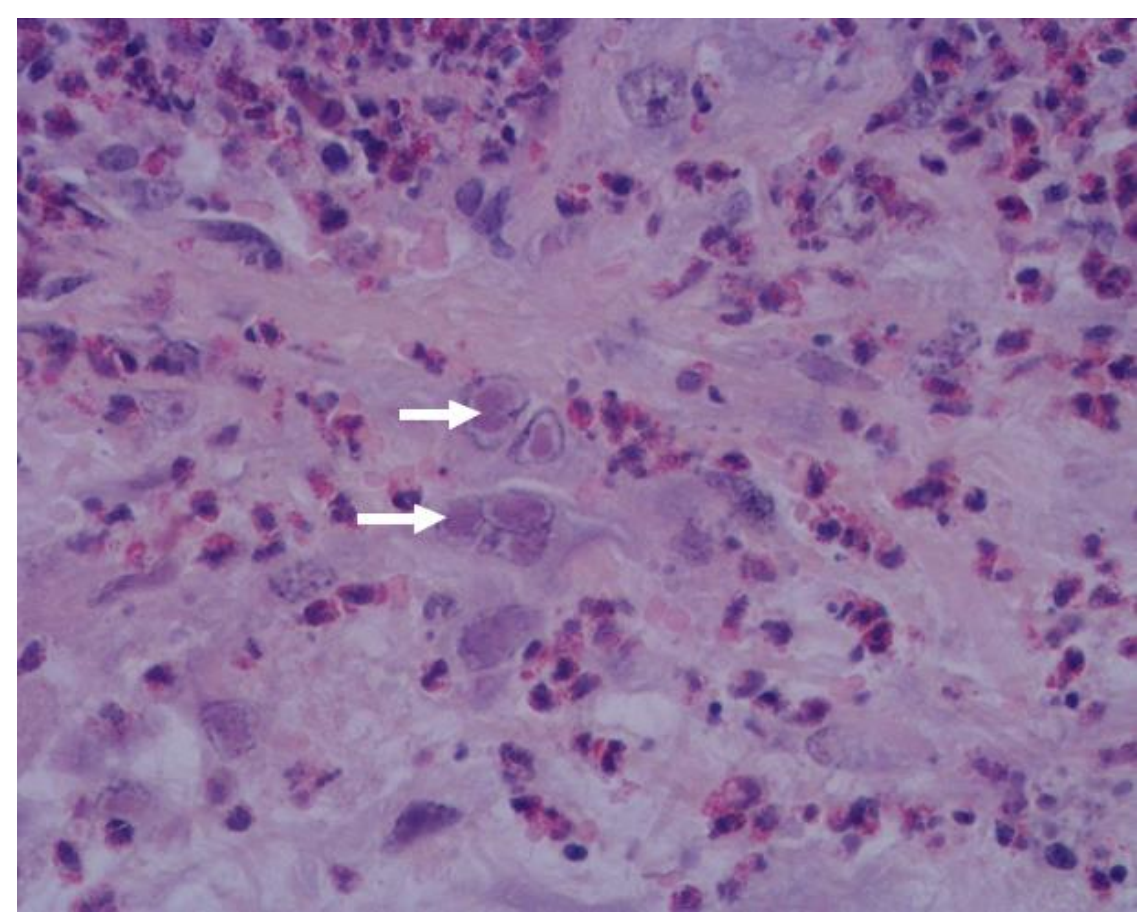

Figure 4 
bioRxiv preprint doi: https://doi.org/10.1101/2020.01.21.913723; this version posted March 21, 2020. The copyright holder for this preprint (which was not certified by peer review) is the author/funder. All rights reserved. No reuse allowed without permission.

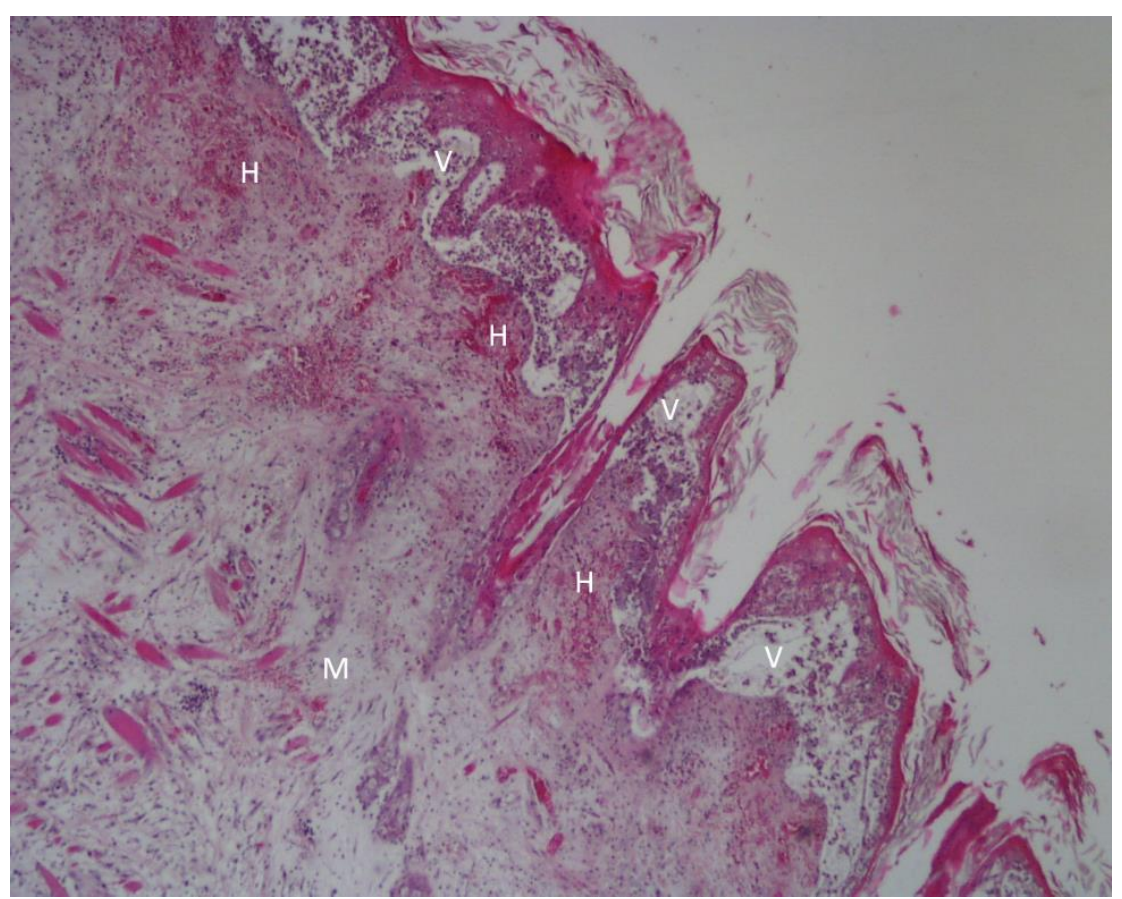

Figure 5 


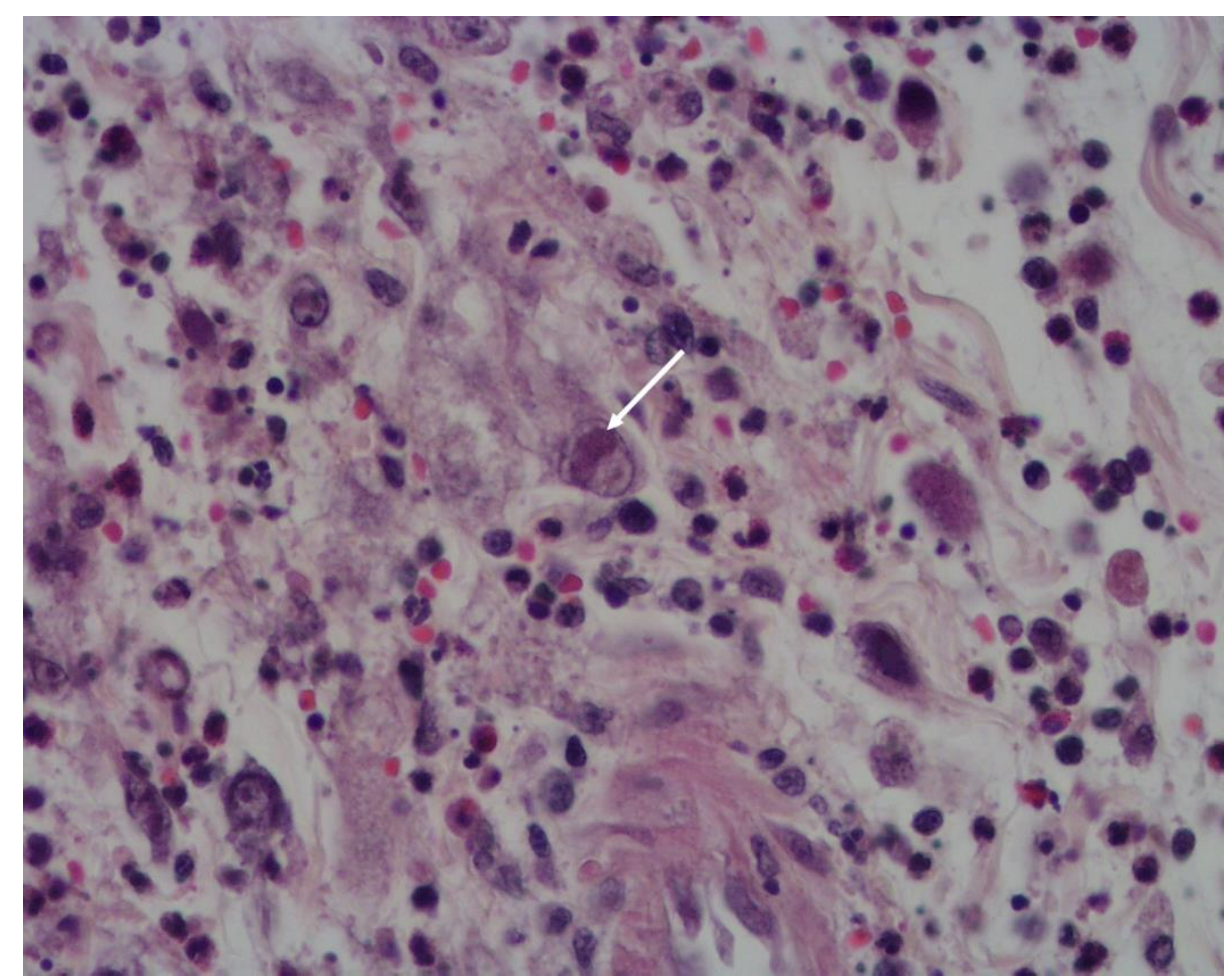

Figure 6 

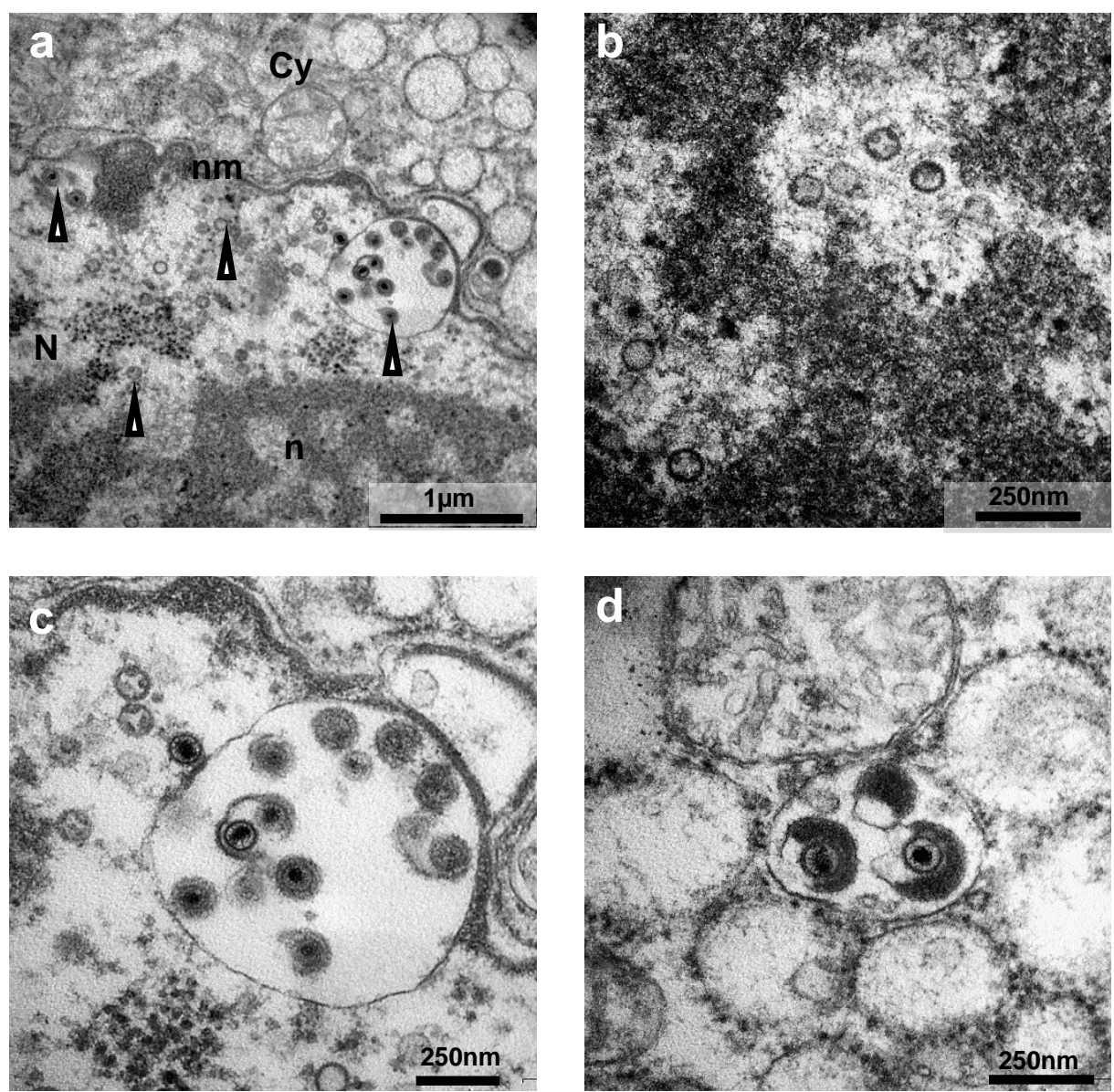

Figure 7 


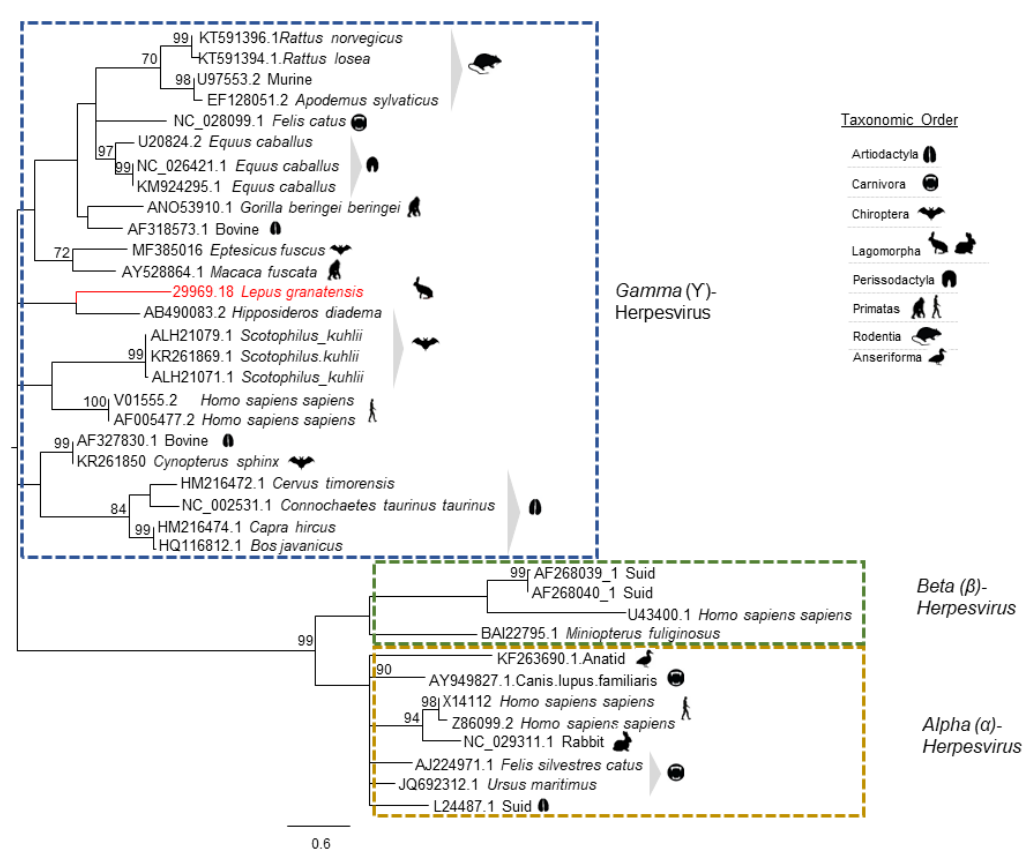

Figure 8 
bioRxiv preprint doi: https://doi.org/10.1101/2020.01.21.913723; this version posted March 21, 2020. The copyright holder for this preprint (which was not certified by peer review) is the author/funder. All rights reserved. No reuse allowed without permission.

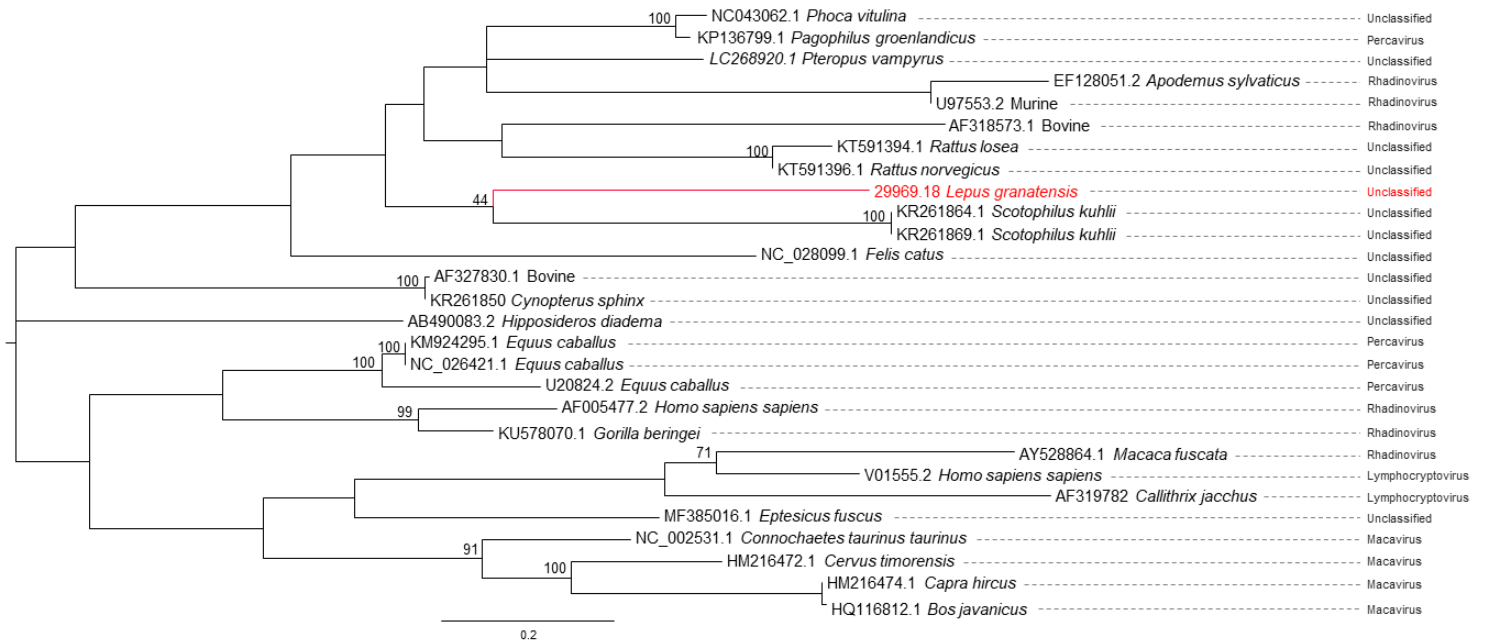

Figure 9 